\title{
ANALISIS PENERAPAN SISTEM MANAJEMEN KESELAMATAN DAN KESEHATAN KERJA PADA PEMBANGUNAN GEDUNG DAN PERUMAHAN
}

\author{
Steven $^{1}$ dan Mega Waty ${ }^{2}$ \\ ${ }^{1}$ Program Studi Sarjana Teknik Sipil, Universitas Tarumanagara, Jl. Letjen S. Parman No.1 Jakarta \\ Steven.325160163@stu.untar.ac.id \\ ${ }^{2}$ Program Studi Sarjana Teknik Sipil, Universitas Tarumanagara, J1. Letjen S. Parman No.1 Jakarta \\ mega@ft.untar.ac.id
}

\begin{abstract}
Indonesia as a developing country in the Asian region is a country that has a lot of development. Occupational safety and health management systems are part of an organization's management system that is used to develop and implement Occupational safety and health policies and manage risks. In this study, researchers will discuss the application of occupational safety and health management systems and supporting facilities for occupational safety and health management systems applied by construction companies to the construction of high rise buildings and housing developments. The method used to determine the successful implementation of the Occupational Safety and Health Management System is to use quantitative methods and Univariate analysis. Later the results of the percentage calculation will be compared with Minister of Public Works Regulation No.9 / 2008 concerning Management and Work Safety Systems. Application of Occupational Safety and Health Management System in high rise buildings is 97\% (Good), and for housing is 35\% (less). The supporting facilities in the high rise building project are $88 \%$ (Good) and $40 \%$ (less) for housing.
\end{abstract}

Keywords: Occupational Safety and Health Management System; Supporting Facilities; High rise building projects; Housing projects.

\begin{abstract}
ABSTRAK
Indonesia sebagai salah satu negara berkembang di kawasan Asia merupakan negara yang banyak melakukan pembangunan. Sistem manajemen keselamatan dan kesehatan kerja merupakan bagian dari sistem manajemen organisasi yang digunakan untuk mengembangkan dan menerapkan kebijakan keselamatan dan kesehatan kerja dan mengelola risiko. Dalam penelitian ini, peneliti akan membahas penerapan sistem manajemen keselamatan dan kesehatan kerja dan fasilitas pendukung sistem manajemen keselamatan dan kesehatan kerja yang diterapkan perusahaan konstruksi terhadap pembangunan gedung bertingkat dan pembangunan perumahan. Metode yang digunakan untuk mengetahui keberhasilan penerapan Sistem Manajemen Keselamatan dan Kesehatan Kerja adalah dengan menggunakan metode kuantitatif dan analisis Univariat. Kemudian hasil perhitungan persentase tersebut akan dibandingkan dengan Peraturan Menteri PU No.9/2008 tentang Sistem Manajemen dan Keselamatan Kerja. Penerapan Sistem Manajemen Keselamatan dan Kesehatan Kerja pada gedung bertingkat didapat 97\% (Baik), dan untuk perumahan didapat 35\% (kurang). Fasilitas pendukung yang ada pada proyek gedung bertingkat didapat $88 \%$ (Baik) dan untuk perumahan didapat $40 \%$ (kurang).
\end{abstract}

Kata kunci: Sistem Manajemen Keselamatan dan Kesehatan Kerja; Fasilitas pendukung; Proyek gedung bertingkat; Proyek perumahan.

\section{PENDAHULUAN}

Indonesia adalah negara yang sedang berkembang di kawasan Asia merupakan negara yang banyak melakukan pembangunan. Pembangunan yang ada tidak hanya bergantung dari manajemen waktu, biaya, dan mutu yang baik, tetapi pelaksanaan konstruksi juga perlu memperhatikan kesehatan dan keselamatan kerja di lingkungan proyek.

Menurut Suraji (2001) tugas dari manajer konstruksi dalam menjaga keselamatan di proyek tidak dapat di anggap remeh. Karena kesehatan dan keselamatan kerja menyangkut nyawa manusia, maka setiap perusahaan konstruksi harus memperhatikan sistem keselamatan dan kemanan kerja (K3). 
Tidak perlu diragukan lagi bahwa masalah tentang keamanan, kesehatan, dan manajemen lingkungan semakin semakin hari semakin meningkat signifikan dari setiap perusahaan konstruksi dan kepada semua orang di (Choudhry, et al., 2008).

Seperti Jacinto (2011) menyatakan, penerapan undang-undang yang benar di perusahaan dapat mencegah dan mengendalikan peristiwa yang tidak diinginkan, dan bahkan mengurangi dampaknya.

Dari pendahuluan diatas dapat disimpulkan bahwa rumusan masalah sebagai berikut:

1. Bagaimana penerapan sistem manajemen keselamatan dan kesehatan kerja di lingkungan proyek pembangunan gedung?

2. Bagaimana penerapan sistem manajemen keselamatan dan kesehatan kerja di lingkungan proyek pembangunan perumahan?

3. Apakah fasilitas yang mendukung keselamatan dan kesehatan kerja di lokasi proyek pembangunan gedung sudah baik?

4. Apakah fasilitas yang mendukung keselamatan dan kesehatan kerja di lokasi proyek pembangunan perumahan sudah baik?

Berikut adalah tujuan penelitian, yang menjawab identifikasi masalah:

1. Mengetahui keberhasilan penerapan sistem keselamatan dan kesehatan kerja di lingkungan proyek pembangunan gedung yang diteliti.

2. Mengetahui keberhasilan penerapan sistem keselamatan dan kesehatan kerja di lingkungan proyek pembangunan perumahan yang diteliti.

3. Mengetahui kelengkapan fasilitas pendukung keselamatan dan kesehatan kerja di lingkungan proyek pembangunan gedung yang diteliti.

4. Mengetahui kelengkapan fasilitas pendukung keselamatan dan kesehatan kerja di lingkungan proyek pembangunan pemahan yang diteliti.

\section{Sistem manajemen keselamatan dan kesehatan kerja}

Sistem manajemen keselamatan dan kesehatan kerja merupakan bagian dari sistem manajemen organisasi yang digunakan untuk mengembangkan dan menerapkan kebijakan K3 dan mengelola risiko (OHSAS 18001, 2007).

\section{Fasilitas pendukung sistem manajemen keselamatan dan kesehatan kerja}

Keselamatan dan kesehatan kerja yang baik tidak hanya mementingkan sistem penerapan yang baik, tetapi perlu juga memperhatikan kelengkapan dalam melaksanakan kegiatan kosntruksi. APD (Alat Pelindung Diri) merupakan salah satu hal wajib dalam melaksanakan kegiatan kosntrusi, selain itu diperlukan juga rambu peringatan dan penanda bahaya sehingga lokasi kegiatan konstruksi lebih aman.

\section{METODE PENELITIAN}

\section{Lokasi penelitian}

lokasi yang menjadi penelitian untuk pengamatan ini, adalah proyek pembangunan gedung bertingkat dan perumahan di sekitar Jakarta.

\section{Variabel penelitian}

Berikut adalah variabel yang digunakan pada penelitian yang dapat dilihat pada tabel 1 dan tabel 2.

Tabel 1. Tabel variabel penelitian

\begin{tabular}{clll}
\hline Variabel & \multicolumn{1}{c}{ Faktor untuk SMK3 } & Sumber \\
\hline X1 & $\begin{array}{l}\text { Apakah perusahaan konstruksi menyediakan sumber daya manusia, } \\
\text { sarana dan dana yang memadai sesuai dengan SMK3 yang akan } \\
\text { diterapkan }\end{array}$ & \\
X2 & $\begin{array}{l}\text { Apakah informasi K3 terbaru dikomunikasikan kepada tenaga kerja } \\
\text { dan pihak terkait dalam perusahaan }\end{array}$ & \\
\hline
\end{tabular}


Tabel 1. Tabel variabel penelitian (Lanjutan)

\begin{tabular}{|c|c|c|}
\hline Variabel & Faktor untuk SMK3 & Sumber \\
\hline X3 & $\begin{array}{l}\text { Apakah semua bagian dari peralatan yang berbahaya telah diberi suatu } \\
\text { tanda-tanda }\end{array}$ & (Bramantya, 2016) \\
\hline $\mathrm{X} 4$ & $\begin{array}{l}\text { Apakah perusahaan memberikan jaminan kesehatan kepada setiap } \\
\text { karyawan }\end{array}$ & (Bramantya, 2016) \\
\hline X5 & $\begin{array}{l}\text { Apakah pemimpin perusahaan konstruksi telah mengambil tanggung } \\
\text { jawab utama dalam K3 dan sistem manajemen K3 }\end{array}$ & (Bramantya, 2016) \\
\hline X6 & $\begin{array}{l}\text { Apakah perusahaan memberikan pelatihan dan pendidikan bagi setiap } \\
\text { kayawan untuk bertindak dengan aman dalam penyelesaian pekerjaan }\end{array}$ & (Bramantya, 2016) \\
\hline $\mathrm{X} 7$ & $\begin{array}{l}\text { Apakah perusahaan memberikan rekasi cepat dan tepat terhadap } \\
\text { kondisi yang menyimpang dan kejadian lainnya }\end{array}$ & (Bramantya, 2016) \\
\hline $\mathrm{X} 8$ & $\begin{array}{l}\text { Apakah dokumen yang diperlukan dan pedoman SMK3 telah } \\
\text { dikendalikan }\end{array}$ & (Bramantya, 2016) \\
\hline X9 & $\begin{array}{l}\text { Apakah perusahaan telah membuat, mengidentifikasi, menerapkan, dan } \\
\text { memelihara prosedur pada situasi tanggap darurat }\end{array}$ & (Bramantya, 2016) \\
\hline $\mathrm{X} 10$ & $\begin{array}{l}\text { Apakah perusahaan membuat ketentuan untuk mengkomunikasikan } \\
\text { informasi keselamatan dan kesehatan kerja secara efektif }\end{array}$ & $\begin{array}{l}\text { (International Labour } \\
\text { Organization Jakarta, 2013) }\end{array}$ \\
\hline $\mathrm{X} 11$ & $\begin{array}{l}\text { Apakah perusahaan membuat peraturan untuk mendapatkan pendapat } \\
\text { dan saran dari para ahli }\end{array}$ & $\begin{array}{l}\text { (International Labour } \\
\text { Organization Jakarta, 2013) }\end{array}$ \\
\hline $\mathrm{X} 12$ & $\begin{array}{l}\text { Apakah perusahaan membuat peraturan untuk pelaksanaan konsultasi } \\
\text { dan keterlibatan tenaga kerja secara aktif }\end{array}$ & $\begin{array}{l}\text { (International Labour } \\
\text { Organization Jakarta, 2013) }\end{array}$ \\
\hline $\mathrm{X} 13$ & $\begin{array}{l}\text { Alat berat dioperasikan oleh operator yang memiliki SIO (Surat Izin } \\
\text { Operasi) dan masih berlaku }\end{array}$ & (Gunara, 2017) \\
\hline X14 & $\begin{array}{l}\text { Apakah inspeksi pengujian dan pemantauan dilakukan oleh personil } \\
\text { yang berpengalaman dan punya keahlian yang cukup }\end{array}$ & (Bramantya, 2016) \\
\hline $\mathrm{X} 15$ & $\begin{array}{l}\text { Apakah peralatan dan metode pengujian yang digunakan cukup } \\
\text { memadai }\end{array}$ & (Bramantya, 2016) \\
\hline $\mathrm{X} 16$ & $\begin{array}{l}\text { Apakah catatan inspeksi, pengujian dan pemantauan terpelihara dengan } \\
\text { baik }\end{array}$ & (Bramantya, 2016) \\
\hline $\mathrm{X} 17$ & Apakah hasil temuan dianalisa dan ditijau ulang & (Bramantya, 2016) \\
\hline $\mathrm{X} 18$ & $\begin{array}{l}\text { Apakah tindakan perbaikan dan pencegahan dilaksanakan berdasarkan } \\
\text { hasil temuan }\end{array}$ & $\begin{array}{l}\text { (International Labour } \\
\text { Organization Jakarta, 2013) }\end{array}$ \\
\hline X19 & $\begin{array}{l}\text { Audit Sistem Manajemen K3 dilakukan secara berkala untuk } \\
\text { mengetahui keefektifan penerapan Sistem Manajemen K3 }\end{array}$ & $\begin{array}{l}\text { (International Labour } \\
\text { Organization Jakarta, 2013) }\end{array}$ \\
\hline $\mathrm{X} 20$ & $\begin{array}{l}\text { Hasil audit digunakan oleh pengurus dalam proses tinjauan ulang } \\
\text { manajemen }\end{array}$ & $\begin{array}{l}\text { (International Labour } \\
\text { Organization Jakarta, 2013) }\end{array}$ \\
\hline $\mathrm{X} 21$ & $\begin{array}{l}\text { Apakah pengurus melakukan tinjauan ulang terhadap SMK3 secara } \\
\text { berkala }\end{array}$ & (Bramantya, 2016) \\
\hline $\mathrm{X} 22$ & $\begin{array}{l}\text { Apakah dilakukan tinjauan ulang dari evaluasi terhadap penerapan } \\
\text { kebijakan K3 }\end{array}$ & (Bramantya, 2016) \\
\hline $\mathrm{X} 23$ & $\begin{array}{l}\text { Apakah dilakukan tijauan ulang terhadap tujuan, sasaran, dan kinerja } \\
\text { K3 }\end{array}$ & (Bramantya, 2016) \\
\hline $\mathrm{X} 24$ & Apakah dilakukan tinjauan ulang dari hasil temuan audit SMK3 & (Bramantya, 2016) \\
\hline $\mathrm{X} 25$ & $\begin{array}{l}\text { Apakah dilakukan tinjauan ulang dari evaluasi efektifitas penerapan } \\
\text { SMK3 }\end{array}$ & (Bramantya, 2016) \\
\hline
\end{tabular}


Tabel 2. Tabel variabel fasilitas pendukung SMK3

\begin{tabular}{ll}
\hline NO & Fasilitas pendukung SMK3 \\
\hline X26 & Helm \\
X27 & Sepatu \\
X28 & Sarung tangan \\
X29 & Rompi \\
X30 & Masker \\
X31 & Jaring pengaman \\
X32 & Rambu-rambu \\
X33 & Hydrant \\
X34 & Spanduk peringatan K3 \\
X35 & Alaram peringatan \\
X36 & Lampu peringatan \\
\hline
\end{tabular}

\section{Analisis deskriptif}

Analisis univariat atau deskriptif merupakan analisis paling dasar yang sering digunakan dalam berbagai jenis penelitian. Metode Analisis Univariat, digunakan untuk mengetahui hasil persentase penerapan SMK3 dengan cara mencari rata-rata dan distribusi frekuensi. Hasil analisis disajikan kedalam tabel distribusi frekuensi dan juga grafik.

\section{HASIL DAN PEMBAHASAN}

\section{Uji validitas}

Berikut adalah contoh uji validitas yang dapat dilihat pada tabel 3.

Tabel 3. Tabel contoh uji validitas

\begin{tabular}{lll}
\hline Variabel & & r hitung \\
\hline X1 & Pearson Correlation &, $832^{* *}$ \\
X2 & Pearson Correlation &, $832^{* *}$ \\
X3 & Pearson Correlation &, $711^{* *}$ \\
\hline
\end{tabular}

Hasil data uji validitas di atas disimpulkan bahwa seluruh $r$ total sudah memenuhi syarat $r$ tabel melebihi $(0,361)$, sehingga data dapat dikatakan valid.

\section{Uji reliabilitas}

Berikut adalah uji reliabilitas yang dapat dilihat pada tabel 4.

Tabel 4. Tabel Uji reliabilias

\section{Reliability Statistics}

\begin{tabular}{r|r}
\hline $\begin{array}{c}\text { Cronbach's } \\
\text { Alpha }\end{array}$ & Nof Items \\
\hline, 967 & 36 \\
\hline
\end{tabular}


Hasil data tabel menunjukan bahwa hasil yang didapat adalah 0,967, dimana hasil yang didapat lebih besar dari 0,6. Dapat disimpulkan berarti data kuesioner dari hasil penelitian ini reliabel. Dan hasil realibilitas dari penelitian ini baik karena berada pada rentang 0,8-1.

\section{Uji normalitas}

Berikut adalah uji normalitas yang dapat dilihat pada tabel 5.

Tabel 5. Tabel uji normalitas

\section{Tests of Normality}

\begin{tabular}{cc|c|c|c|c|c} 
& \multicolumn{3}{c}{ Kolmogorov-Smirnova } & \multicolumn{3}{c}{ Shapiro-Wilk } \\
& Statistic & $d f$ & Sig. & Statistic & $d f$ & Sig. \\
\hline $\begin{array}{c}\text { Proyek gedung } \\
\text { bertingkat }\end{array}$ &, 196 & 15 &, 125 &, 911 & 15 &, 142 \\
\hline Proyek perumahan &, 125 & 15 &, $200^{*}$ &, 944 & 15 &, 435 \\
\hline
\end{tabular}

Hasil tabel menunjukan signifikansinya bernilai 0,142 untuk proyek gedung bertingkat dan 0,435 untuk proyek perumahan, sehingga dapat dikatakan bahwa data yang didapat bersifat normal.

\section{Hasil persentase kuesioner SMK3}

Hasil analisis penerapan pada SMK3 proyek pembangunan gedung bertingkat dan proyek perumahan dapat dilihat pada tabel 6 dan tabel 7 berikut.

Tabel 6. Distribusi frekuensi sistem manajemen kesehatan dan keselamatan kerja pada proyek gedung bertingkat

\begin{tabular}{ccccc}
\hline No. & $\begin{array}{c}\text { Penerapan dan } \\
\text { Operasi Kegiatan (\%) }\end{array}$ & $\begin{array}{c}\text { Evaluasi/ } \\
\text { Pemeriksaan }(\%)\end{array}$ & $\begin{array}{c}\text { Tinjauan } \\
\text { Manajemen }(\%)\end{array}$ & $\begin{array}{c}\text { Rata-rata } \\
(\%)\end{array}$ \\
\hline 1 & $77 \%$ & $57 \%$ & $60 \%$ & $65 \%$ \\
2 & $100 \%$ & $100 \%$ & $100 \%$ & $100 \%$ \\
3 & $92 \%$ & $86 \%$ & $100 \%$ & $93 \%$ \\
4 & $100 \%$ & $100 \%$ & $100 \%$ & $100 \%$ \\
5 & $100 \%$ & $100 \%$ & $100 \%$ & $100 \%$ \\
6 & $100 \%$ & $100 \%$ & $100 \%$ & $100 \%$ \\
7 & $100 \%$ & $100 \%$ & $100 \%$ & $100 \%$ \\
8 & $100 \%$ & $100 \%$ & $100 \%$ & $100 \%$ \\
9 & $100 \%$ & $100 \%$ & $100 \%$ & $100 \%$ \\
10 & $100 \%$ & $100 \%$ & $100 \%$ & $100 \%$ \\
11 & $100 \%$ & $100 \%$ & $100 \%$ & $100 \%$ \\
12 & $100 \%$ & $100 \%$ & $100 \%$ & $100 \%$ \\
13 & $100 \%$ & $100 \%$ & $100 \%$ & $100 \%$ \\
14 & $100 \%$ & $100 \%$ & $100 \%$ & $100 \%$ \\
15 & $100 \%$ & $100 \%$ & $100 \%$ & $100 \%$ \\
Rata-rata & & & $97 \%$ & $97 \%$ \\
\hline$\%$ & $98 \%$ & $96 \%$ & & \\
\hline
\end{tabular}


Tabel 7. Distribusi frekuensi sistem manajemen kesehatan dan keselamatan kerja pada proyek perumahan

\begin{tabular}{|c|c|c|c|c|}
\hline NO & $\begin{array}{c}\text { Penerapan dan } \\
\text { Operasi Kegitan } \\
(\%)\end{array}$ & $\begin{array}{c}\text { Evaluasi/ } \\
\text { Pemeriksaan }(\%)\end{array}$ & $\begin{array}{c}\text { Tinjauan } \\
\text { Manajemen }(\%)\end{array}$ & $\begin{array}{c}\text { Rata-rata } \\
(\%)\end{array}$ \\
\hline 1 & $23 \%$ & $57 \%$ & $0 \%$ & $27 \%$ \\
\hline 2 & $23 \%$ & $57 \%$ & $0 \%$ & $27 \%$ \\
\hline 3 & $23 \%$ & $57 \%$ & $0 \%$ & $27 \%$ \\
\hline 4 & $0 \%$ & $0 \%$ & $0 \%$ & $0 \%$ \\
\hline 5 & $0 \%$ & $0 \%$ & $0 \%$ & $0 \%$ \\
\hline 6 & $0 \%$ & $0 \%$ & $0 \%$ & $0 \%$ \\
\hline 7 & $23 \%$ & $57 \%$ & $0 \%$ & $27 \%$ \\
\hline 8 & $69 \%$ & $71 \%$ & $60 \%$ & $67 \%$ \\
\hline 9 & $77 \%$ & $100 \%$ & $20 \%$ & $66 \%$ \\
\hline 10 & $69 \%$ & $71 \%$ & $60 \%$ & $67 \%$ \\
\hline 11 & $23 \%$ & $57 \%$ & $0 \%$ & $27 \%$ \\
\hline 12 & $15 \%$ & $71 \%$ & $0 \%$ & $29 \%$ \\
\hline 13 & $69 \%$ & $86 \%$ & $0 \%$ & $52 \%$ \\
\hline 14 & $77 \%$ & $71 \%$ & $0 \%$ & $49 \%$ \\
\hline 15 & $92 \%$ & $71 \%$ & $0 \%$ & $55 \%$ \\
\hline $\begin{array}{l}\text { Rata-rata } \\
(\%)\end{array}$ & $39 \%$ & $55 \%$ & $9 \%$ & $35 \%$ \\
\hline
\end{tabular}

Dilihat dari SMK3 seluruh kegiatan sudah mencapai nilai 97\% untuk proyek gedung bertingkat, yang menunjukan bahwa penerapannya sudah dilaksanakan dengan baik. Sedangkan untuk proyek perumahan persentase seluruh kegiatannya mencapai nilai $35 \%$, yang menunjukan bahwa penerapannya masih kurang. Hal ini dapat dilihat dari peraturan:

- $\quad$ Baik, bila hasil penilaian mencapai $>85 \%$

- Sedang, bila hasil penilaian mencapai $60 \%-85 \%$

- Kurang, bila hasil penilaian mencapai $<60 \%$

\section{Persentase kuesioner fasilitas pendukung SMK3}

Hasil analisis persentase kelengkapan fasilitas pendukung SMK3 dapat dilihat pada tabel 8 dan tabel 9 berikut.

Tabel 8. Persentase kelengkapan fasilitas pendukung SMK3 pada proyek gedung bertingkat

\begin{tabular}{lccccccc}
\hline \multicolumn{1}{c}{ Item } & 1 & 2 & 3 & 4 & 5 & Nilai & Nilai (\%) \\
\hline Helm & 0 & 0 & 0 & 0 & 15 & 75 & $100 \%$ \\
Sepatu & 0 & 0 & 0 & 0 & 15 & 75 & $100 \%$ \\
Sarung tangan & 1 & 0 & 2 & 0 & 12 & 67 & $89 \%$ \\
Rompi & 0 & 0 & 0 & 0 & 15 & 75 & $100 \%$ \\
Masker & 0 & 0 & 6 & 1 & 8 & 62 & $83 \%$ \\
Jaring pengaman & 0 & 0 & 4 & 4 & 7 & 63 & $84 \%$ \\
Rambu-rambu & 0 & 0 & 0 & 6 & 9 & 69 & $92 \%$
\end{tabular}


Tabel 8. Persentase kelengkapan fasilitas pendukung SMK3 pada proyek gedung bertingkat (Lanjutan)

\begin{tabular}{lccccccc}
\hline \multicolumn{1}{c}{ Item } & 1 & 2 & 3 & 4 & 5 & Nilai & Nilai (\%) \\
\hline Alat pemadam api ringan & 0 & 0 & 1 & 1 & 13 & 72 & $96 \%$ \\
Spanduk peringatan K3 & 0 & 0 & 0 & 5 & 10 & 70 & $93 \%$ \\
Alaram peringatan & 3 & 0 & 5 & 4 & 3 & 49 & $65 \%$ \\
Lampu peringatan & 0 & 0 & 9 & 4 & 2 & 53 & $71 \%$ \\
Jumlah & & & & \\
\multicolumn{2}{c}{ Persentase= (jumlah/skor ideal) x 100\% } \\
\end{tabular}

Tabel 9. Persentase kelengkapan fasilitas pendukung SMK3 pada proyek perumahan

\begin{tabular}{|c|c|c|c|c|c|c|c|}
\hline Item & 1 & 2 & 3 & 4 & 5 & Nilai & Nilai (\%) \\
\hline Helm & 3 & 1 & 6 & 4 & 1 & 44 & $59 \%$ \\
\hline Sepatu & 3 & 4 & 6 & 1 & 1 & 38 & $51 \%$ \\
\hline Sarung tangan & 9 & 1 & 4 & 0 & 1 & 28 & $37 \%$ \\
\hline Rompi & 12 & 0 & 2 & 0 & 1 & 23 & $31 \%$ \\
\hline Masker & 8 & 8 & 0 & 4 & 1 & 45 & $60 \%$ \\
\hline Jaring pengaman & 8 & 6 & 1 & 0 & 0 & 23 & $31 \%$ \\
\hline Rambu-rambu & 12 & 0 & 3 & 0 & 0 & 21 & $28 \%$ \\
\hline Alat pemadam api ringan & 5 & 0 & 0 & 7 & 3 & 48 & $64 \%$ \\
\hline Spanduk peringatan K3 & 12 & 0 & 1 & 0 & 2 & 25 & $33 \%$ \\
\hline Alaram peringatan & 15 & 0 & 0 & 0 & 0 & 15 & $20 \%$ \\
\hline Lampu peringatan & 13 & 1 & 1 & 0 & 0 & 18 & $24 \%$ \\
\hline Jumlah & & & & & 825 & 328 & \\
\hline \multicolumn{7}{|c|}{ Persentase $=($ jumlah/skor ideal $) \times 100 \%$} & $40 \%$ \\
\hline
\end{tabular}

Dilihat di atas disimpulkan bahwa persentase kelengkapan fasilitas pendukung SMK3 pada proyek gedung bertingkat didapat angka $88 \%$ seperti penjelasan sebelumnya, dapat dikatakan bahwa fasilitas pendukung yang ada baik. Dan persentase kelengkapan fasilitas pendukung SMK3 pada proyek perumahan mencapai angka $40 \%$ seperti penjelasan sebelumnya, dapat dikatakan bahwa fasilitas pendukung yang ada kurang.

\section{KESIMPULAN DAN SARAN}

Berdasarkan analisis yang sudah dilakukan dalam penelitian, dan menjawab rumusan masalah disimpulkan:

1. Berdasarkan hasil dari penelitian yang didapat dari kontraktor IPR, penerapan sistem manajemen keselamatan dan kesehatan kerja untuk proyek pembangunan gedung bertingkat adalah 97\% dimana dapat kita ketahui bahwa penerapan SMK3 yang dilakukan baik.

2. Berdasarkan hasil dari penelitian yang didapat dari kontraktor GA, AT, TJK, IMP, KBM, dan WO, penerapan sistem manajemen keselamatan dan kesehatan kerja untuk proyek pembangunan perumahan diperoleh hasil $35 \%$ dimana dapat kita ketahui bahwa penerapan SMK3 yang dilakukan kurang.

3. Hasil analisis ketersediaan dan kelengkapan fasilitas-fasilitas pedukung sistem manajemen keselamatan dan kesehatan kerja yang didapat dari kontraktor IPR, berada di kisaran 88\%, dimana dapat kita ketahui bahwa fasilitas SMK3 yang ada baik. 
4. Hasil analisis ketersediaan dan kelengkapan fasilitas pendukung sistem manajemen keselamatan dan kesehatan kerja yang didapat dari kontraktor GA, AT, TJK, IMP, KBM, dan WO pada proyek perumahan, berada di kisaran 40\%, dimana dapat kita ketahui bahwa fasilitas SMK3 yang ada kurang.

Saran yang dapat diberikan dari kesimpulan diatas adalah:

1. Penerapan SMK3 yang dilakukan oleh perusahaan pembangunan gedung bertingkat sudah baik, diharapkan perusahaan dapat mempertahankan penerapan SMK3 yang sudah berjalan.

2. Penerapan SMK3 yang dilakukan oleh perusahaan pembangunan perumahan masih kurang, diharapkan perusahaan dapat meningkatkan SMK3 yang diterapkan, karena sekarang ini para owner tidak hanya memperhatikan hasil akhir pembangunan tetapi juga memperhatikan keamanan dan kebersihan lingkungan proyek.

3. Fasilitas pendukung SMK3 yang ada pada proyek gedung bertingkat sangat baik, perusahaan atau kontraktor diharapkan dapat mempertahankan atau meningkatkan fasilitas yang diterapkan pada proyek pembangunan.

4. Fasilitas pendukung SMK3 yang ada pada proyek perumahan buruk, perusahaan atau kontraktor diharapkan dapat meningkatkan fasilitas yang diterapkan pada proyek pembangunan sehingga keamanan pekerja lebih terjamin.

5. Untuk penelitian selanjutnya dapat dilakukan observasi lapangan. Batasan tersebut dapat diperluas dengan menganalisis selain gedung bertingkat, seperti proyek pembangunan jalan, bendungan, serta memperluas daerah pengambilan data proyek di luar Jakarta.

\section{DAFTAR PUSTAKA}

Bramantya, D. Skripsi Penerapan Sistem Manajemen Keselamatan Dan Kesehatan Kerja Di Lingkungan Proyek Pembangunan MidTown Hotel Samarinda. Samarinda: Universitas 17 Agustus, 2016.

Choudhry, Rafiq, M., Dongping Fang and Syed M. Ahmed. "Safety Management in Construction: Best Practice in Hong Kong." Journal of professional issues in engineering education and practice ASCE (2008).

Fisk, E. R. Construction project: adminisration. New Jersey: Prentice Hall, 1992.

Gunara, S. Buku Pedoman Pelaksanaan Keselamatan dan Kesehatan Kerja . Jakarta, 2017.

Jacinto, C., Guendes, S. C., Fialho, T., Silva, A. S. "The Recording Investigation And Analiysis Of Accident At Work." Policy and Practice in Health and Safety 2011.

Organization, International Labour. Keselamatan dan Kesehatan Kerja di Tempat Kerja. Vol. 5. Jakarta, 2013.

OHSAS 18001:2007 Occupational Health and Safety Management Certification.

Suraji, A., A. R. Duff and S. J. Peckitt. "Development of casual model of construction accident causation." Journal of Construction Engineering Management 2001. 